\title{
Quality of health care: patient satisfaction in a university hospital
}

\author{
Qualidadeda assistência à saúde: satisfação de pacientes em um \\ hospital universitário
}

\author{
Denise Fornazari de Oliveira ${ }^{1}$ \\ Carlos Eduardo Leite Arieta ${ }^{2}$ \\ Edméa Rita Temporini ${ }^{3}$ \\ Newton Kara-José ${ }^{4}$
}

Trabalho realizado na Disciplina de Oftalmologia da Faculdade de Ciências Médicas da Universidade Estadual de Campinas - UNICAMP - Campinas (SP) - Brasil.

Pós-graduanda da Faculdade de Ciências Médicas da Universidade Estadual de Campinas - UNICAMP Campinas (SP) - Brasil.

2 Professor livre docente da UNICAMP - Campinas (SP) - Brasil

${ }^{3}$ Professora livre docente Faculdade de Saúde Pública da Universidade de São Paulo - USP - São Paulo (SP) - Brasil.

${ }^{4}$ Professor Titular da Disciplina de Oftalmologia da UNICAMP - Campinas (SP) - Brasil e da USP - São Paulo (SP) - Brasil.

Endereço para correspondência: Denise Fornazari de Oliveira. Rua Giuseppe Maximo Scolfaro, 371 - Casa 19

- Campinas (SP) CEP 13083-100

E-mail: denise.fornazari@uol.com.br

Recebido para publicação em 11.07.2005

Última versão recebida em 22.12.2005

Aprovação em 15.02.2006

\begin{tabular}{l} 
ABSTRACT \\
\hline Objective: To evaluate patient characteristics and satisfaction in an \\
outpatient service at a university hospital, aiming at obtaining subsidies \\
for standardization of a quality assessment program. Method: Patient- \\
representative sample was selected. It consisted of users of the Ophthal- \\
mology Outpatient Service at the Hospital das Clínicas, Universidade \\
Estadual de Campinas (UNICAMP). A structured questionnaire was \\
applied through interview, including the following variables: personal \\
characteristics (gender, age, literacy, job), type of appointment (new \\
patient, follow-up), waiting timeforthe first appointment, opinion regarding \\
ease of access to the hospital, assistance at the front desk, time spent in \\
the waiting room on the appointed day, quality of care, degree of satisfaction \\
with the consultation and general evaluation of the assistance. Results: \\
The sample was characterized by patients with low literacy and socioeco- \\
nomic level; $21.7 \%$ had a steady income. The majority of them think that \\
itis easy to obtain an appointment. According to patients, the mean waiting \\
time for the appointment was 94.6 minutes and $45.3 \%$ of them received no \\
orientation after the appointment. Final evaluation of the quality of \\
assistance was positive and patients were satisfied with the provided \\
assistance. Conclusion: Although a high level of satisfaction regarding \\
the provided service was observed, when the various factors that can \\
affect patient satisfaction are considered, users reported limitations as \\
concerns quality. Evaluation allowed abetter knowledge about the provided \\
service in a university hospitaland pointed to the possibility of implantation \\
of quality assessment routines.
\end{tabular}

Keywords: Patient satisfaction; Consumer satisfaction; Quality of health care; Health care quality, access and evaluation; Quality assurance, health care

\section{INTRODUCTION}

As a result of a weakened market in the health care segment, the providers of these services are becoming increasingly committed to the satisfaction of users' requirements. Regarding public health, the majority of services is not motivated by profit; the system operates at a low degree of competitiveness and, therefore, quality programs are either not a priority or are focused on quantification of quality aspects that are more related to efficiency and effectiveness than to total quality ${ }^{(1)}$. Mechanisms of evaluation of health services are tools of utmost importance in the depiction of what should be a desirable and economically accessible health system for the country and essentially require a discussion on quality ${ }^{(2)}$.

Donabedian $^{(3)}$ raised a series of questions about the elements that form 
quality as a mandatory requirement for health services, positioning user satisfaction as an important element within that definition. This is a major component of quality and care, considered a goal to be reached. Satisfaction measurement is a relevant instrument for administration and planning, in addition to playing an important role in the interaction between service provider and user, since satisfaction reflects judgment of the quality of provided care ${ }^{(2,4)}$.

There are only a few studies that evaluate quality of service in ophthalmology regarding users' satisfaction. Awareness of these data benefits especially managers in the health sector, facilitating the practice of decision-making ${ }^{(5-7)}$. In addition, quality evaluation through measurement of users' satisfaction is part of the hospitals accrediting process, which is under implementation within the health services in Brazil.

This study evaluates users' characteristics and satisfaction in the ophthalmologic clinic at a university hospital, aiming at the obtainment of subsidies for planning patterns for better quality of health care system.

\section{METHOD}

A cross-sectional survey was conducted on patients' characteristics and opinions about the ophthalmologic clinic at the Hospital das Clínicas (HC) at UNICAMP, related to the quality of provided eye health service. This is a didactic/ assistance service within the SUS - Sistema Único de Saúde (Brazilian public health system), which performs tertiary assistance to referenced patients.

A certain number of patients attended during each month by the ophthalmic service (on both first-time and return visits), excluding emergencies, formed the sample. Calculation of this sample size proportional to infinite population was performed, so as to result in a significant sample of the represented population. A representative and non-probabilistic sample was obtained.

The following variables were studied: sex, age, literacy and practice of compensated activity (for determination of social/ economic level); waiting time before visit and opinion on ease of access to the service; opinion on the reception service; time spent in the waiting room before being attended; physician's care and service provided by the ophthalmic staff in general (to evaluate user satisfaction).

A structured questionnaire based on an exploratory study was applied by interviewing the patients. Questionnaire validation was conducted through application of two previous tests. Difficulties to understand and answer the questions were assessed and solved during those tests. The final questionnaire consisted of 34 questions, and the results of 23 were included in this study.

Data collection took place at the ophthalmology outpatient clinic by three previously trained persons of the research personnel. The interviewers approached the patients in the order in which they exited the room for post-visit procedure, inviting them to participate in the survey. The interviews took place during the months of April and March, 2003, during all periods of the day, to make sure that the sample had patients from all subspecialties. For patients under the age of eighteen the accompanying person was interviewed. Due to some patients' private reasons (transportation schedule, other commitments), some refused to participate in the interview, not surpassing $1.0 \%$ of all cases.

A database utilizing the SPSS V10 software was created for the analysis of the data obtained. Distribution of frequency and position and dispersion measurements were performed whenever the variables were continuous. Upon association of variables through analysis of the observed proportions, the application of the statistical test was not indicated.

\section{RESULTS}

The sample included 1,129 patients (sample calculation based on a population of 48,405 patients attended over one year); $532(47.1 \%)$ males and $597(52.9 \%)$ females. We interviewed 1,040 patients $(92.1 \%)$ on return visit and 89 patients $(7.9 \%)$ on first-time type of visit.

Ages varied from one to 91 years, with an average of 46.5 years, standard deviation of 25.4 years and median of 53 years. Concerning literacy, $50.8 \%$ of the patients had completed the fourth grade of elementary school. Among patients over 15 years of age ( $n=926), 49.1 \%$ had completed the first four grades.

Of all patients 15 years of age and older $(n=926), 201$ $(21.7 \%)$ had a paid activity. In the group that was 50 years old or more, $66(7.1 \%)$ patients had paid jobs. Among occupations of these patients, manual services, specialized or not, prevailed (64.7\%).

Patients declared that one visit to $\mathrm{HC}$ was necessary, in order to make an appointment for the first visit (69.0\%), two visits were required $(11.0 \%)$, three trips were demanded (7.0\%), while $13.0 \%$ declared not being able to return. Waiting time for visit was less than 30 days for $79.3 \%$ of the cases, from 30 to 60 days for $10.2 \%$ of the cases, while $15.9 \%$ of the patients declared having waited for more than 60 days (average of 34.7 days). The majority of patients $(69.1 \%)$ considered it easy to make an appointment at the ophthalmic clinic.

Regarding service provided by the ophthalmology clinic reception personnel, $98.0 \%$ of the patients stated as having been "respectfully treated", while $93.6 \%$ declared having received all information requested in relation to the service. When asked about information received while waiting for the visit, $77.7 \%$ declared not having received the information. $92.3 \%$ of the patients considered the service to be good or excellent (Table 1).

The declared waiting time for medical consultation was 96.4 minutes on average; and equal to or less than 60 minutes for $53.9 \%$ of the patients (Table 2). Table 3 shows that the waiting time for a visit does not affect the opinion on quality of service.

When quality of service was analyzed regarding literacy 
and practice of paid activity the opinion was not different among the subgroups. Service provided was rated as good for more than $90,0 \%$ of the subjects who were interviewed.

Considering medical services, $58.7 \%$ of the patients declared that the physician did not "introduce himself", i.e., did not declare his/her name and function; $97.2 \%$ reported the professional to be attentive; $85.2 \%$ had the opportunity to pose questions and $78.8 \%$ received explanations related to their own visual problems (Table 4). The quality of the eye

\begin{tabular}{|c|c|c|}
\hline Opinion & $f$ & $\%$ \\
\hline \multicolumn{3}{|c|}{ Regarding service at the reception desk } \\
\hline Excellent & 526 & 46.6 \\
\hline Good & 516 & 45.7 \\
\hline Fair & 70 & 6.2 \\
\hline Bad & 3 & 0.3 \\
\hline Very bad & 6 & 0.5 \\
\hline No opinion & 8 & 0.7 \\
\hline \multicolumn{3}{|c|}{ Regarding overall service } \\
\hline Good & 1046 & 92.6 \\
\hline Fair & 67 & 5.9 \\
\hline Bad & 5 & 0.4 \\
\hline No opinion & 11 & 1.0 \\
\hline$f=$ frequency; $n=$ & & \\
\hline
\end{tabular}

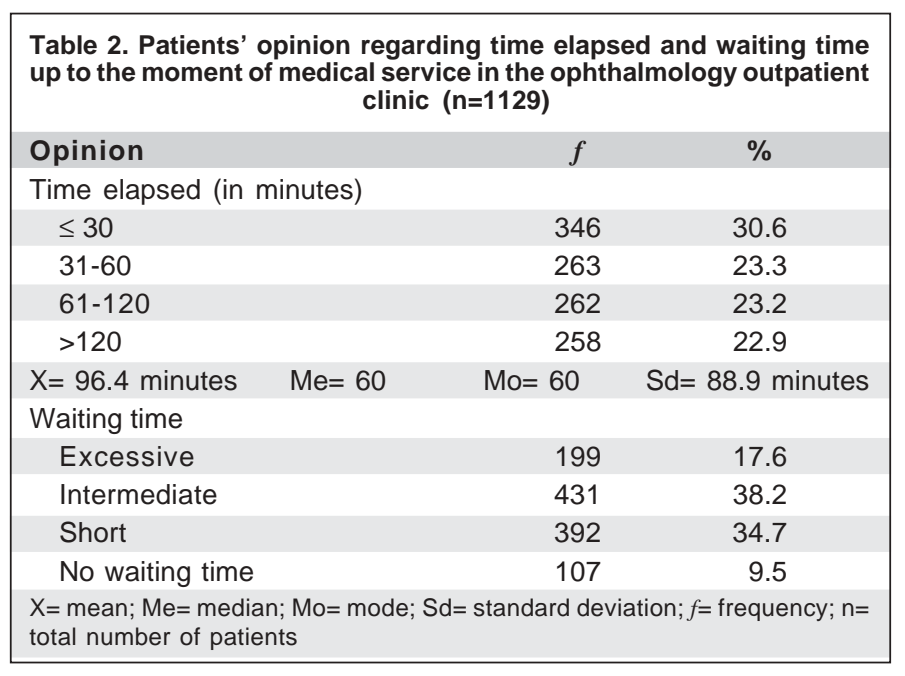

health attention received was classified as good by $92.6 \%$ of the patients (Table 1). During post-visit, 15.4\% declared having received orientation; 511 patients $(45.3 \%)$ declared not having received any.

With the objective of verifying possible differences, a cross-analysis of the variables related to opinion on service quality and type of visit (first-time and return) was established. No significant difference was determined (Table 5). On examination of the proportions, $82.4 \%$ of the patients declared to be very satisfied with the service.

\section{DISCUSSION}

To measure user satisfaction in the health service is not a simple task. Contrary to what happens in the area of service provision, which takes public opinion into high account, satisfaction expressed by users in the health sector is generally seen with disinterest or even suspicion ${ }^{(8-9)}$. Nevertheless, evaluation of quality must be based on both objective and subjective criteria, the latter being those related to the users ${ }^{(4)}$.

Analysis of the characteristics in the sample has indicated the prevalence of individuals over 50 years of age, which can be explained by the nature of the specialty. Ophthalmology services a large number of patients within that age range, which coincides with the increasing incidence of ocular degenerative diseases.

In the 15 to 49-year-old age range, a limited proportion of individuals has a paid activity, contrary to what would be expected from individuals in that age range. Few of the patients over 50 years of age have a paid activity, probably because already retired individuals through the public social welfare system may be included here. In respect to literacy, a greater proportion of patients at the lower levels was found. Literacy is an important indicator of the socioeconomic level and, up to a certain point, reflects the social status of the family. This being a health service that assists only patients from the public health system, who usually do not have access to any other medical assistance, it is expected to find patients of the low classes mainly. The type of professional activity more frequently detected also reflects that same reality, i.e., that of manual workers, which in general is associated with low levels of literacy. Low literacy and low socioeconomic levels characterize the majority of the population that makes use of the public health service in Brazil ${ }^{(10)}$.

\begin{tabular}{|c|c|c|c|c|c|c|c|c|c|c|}
\hline \multirow{3}{*}{$\begin{array}{l}\text { Waiting } \\
\text { time }\end{array}$} & \multicolumn{10}{|c|}{ Evaluation } \\
\hline & \multicolumn{2}{|c|}{ Good } & \multicolumn{2}{|c|}{ Fair } & \multicolumn{2}{|c|}{ Bad } & \multicolumn{2}{|c|}{ No opinion } & \multicolumn{2}{|c|}{ Total } \\
\hline & $f$ & $\%$ & $f$ & $\%$ & $f$ & $\%$ & $f$ & $\%$ & $f$ & $\%$ \\
\hline$\leq 30$ & 337 & 97.4 & 7 & 2.0 & 1 & 0.3 & 1 & 0.3 & 346 & 100.0 \\
\hline $31-60$ & 242 & 92.1 & 17 & 6.5 & 2 & 0.7 & 2 & 0.7 & 263 & 100.0 \\
\hline $61-120$ & 243 & 92.7 & 14 & 5.3 & 1 & 0.4 & 4 & 1.6 & 262 & 100.0 \\
\hline$>120$ & 224 & 86.8 & 29 & 11.2 & 1 & 0.4 & 4 & 1.6 & 258 & 100.0 \\
\hline$f=$ frequenc & & & & & & & & & & \\
\hline
\end{tabular}


The majority of patients have found it easy to make an appointment. The need for establishing a service that optimizes time utilization usually affects the user opinion, since it means fewer expenses with transportation and less loss of working time ${ }^{(11-12)}$. Both factors strongly indicate the facilitation to access to treatment. The implementation of changes already made for the ophthalmology clinic at UNICAMP had significant results that were documented by previous studies, such as an increase in the number of performed cataract surgeries and a decrease in the number of pre surgery visits ${ }^{(13-14)}$. Results obtained through this study also reflect the changes that have occurred: subjects stated the need for only one visit to make an appointment and waiting time up to the first visit to be under 30 days.

The reception service has been indicated as satisfactory by the majority of those who were interviewed. Nevertheless, they declared not having received information about the waiting time to receive the service. One must note that the reception service is what causes the first impression upon the patient, regarding the hospital. An organized reception servi-

\begin{tabular}{|c|c|c|}
\hline Opinion & $f$ & $\%$ \\
\hline \multicolumn{3}{|l|}{ Physician introduced himself } \\
\hline Yes & 418 & 37.0 \\
\hline No & 663 & 58.7 \\
\hline Cannot recall & 48 & 4.3 \\
\hline \multicolumn{3}{|c|}{ Received explanations on their ocular condition } \\
\hline Yes, and understood them totally & 890 & 78.8 \\
\hline Yes, and understood them partially & 145 & 12.8 \\
\hline Yes, but did not understand & 14 & 1.2 \\
\hline No explanation received & 80 & 7.1 \\
\hline \multicolumn{3}{|l|}{ Chances to pose questions } \\
\hline Yes & 962 & 85.2 \\
\hline No & 167 & 14.8 \\
\hline \multicolumn{3}{|l|}{ Physician was attentive } \\
\hline Yes & 1098 & 97.2 \\
\hline No & 28 & 2.5 \\
\hline No opinion & 3 & 0.3 \\
\hline \multicolumn{3}{|l|}{ Impression caused by the physician } \\
\hline Good & 1078 & 98.5 \\
\hline Fair & 36 & 3.2 \\
\hline $\mathrm{Bad}$ & 9 & 0.8 \\
\hline No opinion & 6 & 0.5 \\
\hline$f=$ frequency; $\mathrm{n}=$ total number of patients & & \\
\hline
\end{tabular}

ce, which facilitates the appointments, generates a positive expectation regarding hospital assistance ${ }^{(15-16)}$.

Subjects declared on the day of service an average waiting time for the visit, of about 90 minutes; however, a few of them stated having waiting time was long (Table 1). The characteristic of a teaching hospital relies on the professor/student/resident physician structure for service, which extends the time consumed by visits. In spite of this justification, the "waiting time" factor must be considered as an important objective to be introduced in a process of active intervention, since it is usually one of the major reasons for patients' complaints ${ }^{(9)}$. The average waiting time seems to be acceptable and did not, throughout this study, interfere with the evaluation of service quality, differently from other surveys ${ }^{(9-10)}$.

The evaluation of physicians during the visit was positive regarding the investigated aspects. Attention is called to the fact that most of the physicians do not introduce themselves to the patients during the visit. Maybe concerned with the medical task about to be performed, resident physicians, who most of the time establish the first medical contact with the patient, overlook creating that link. In addition, at each return visit, service may be provided by a different professional, according to a scheduling. In public health services, doctorpatient relationships tend to be impersonal, a link being formed with the service itself, but not between people. The link established in a doctor-patient relationship is one of the essential elements for the creation of a quality practice, allowing for the increase in efficiency of health actions ${ }^{(16)}$.

One observes through the results that evaluation of service provided by the physician tends to be positive upon stating good impression and attention. In the same way, individuals reported the opportunity they had to pose questions and having received explanations about their ocular problem (Table 4).

Explanations given by doctors are frequently forgotten or not understood, and as a result of this poor communication, recommendations are frequently not followed. In spite of stating that he/she understood the explanation, the interviewed subject may have felt ashamed to declare having difficulties in understanding the medical jargon.

Although a high level of satisfaction declared by the subjects regarding the provided service has been observed, when different factors that may affect the satisfaction are raised, it is verified that they do indicate limitations that compromise quality of rendered services, like, for example, the absence of orientation after the medical visit.

\begin{tabular}{|c|c|c|c|c|c|c|c|c|c|c|}
\hline \multirow[b]{3}{*}{ Consultation } & \multicolumn{10}{|c|}{ Opinion } \\
\hline & \multicolumn{2}{|c|}{ Good } & \multicolumn{2}{|c|}{ Fair } & \multicolumn{2}{|c|}{ Bad } & \multicolumn{2}{|c|}{ No opinion } & \multicolumn{2}{|c|}{ Total } \\
\hline & $f$ & $\%$ & $f$ & $\%$ & $f$ & $\%$ & $f$ & $\%$ & $f$ & $\%$ \\
\hline First time & 80 & 89.9 & 7 & 7.9 & 1 & 1.1 & 1 & 1.1 & 89 & 100.0 \\
\hline Return & 966 & 92.9 & 60 & 5.8 & 4 & 0.4 & 10 & 0.9 & 1040 & 100.0 \\
\hline
\end{tabular}


Post-visit quality is one of the factors that may affect service satisfaction and efficiency. The continuity established by post-visit informative and educative actions is part of service quality. Lack of this information by the health team about the treatment to be given may cause unnecessary returns. Would an efficient health education program exist, with participation of physicians and health care professionals, many patients would be able to adjust their social needs to their health conditions, thus resulting in the decrease of unnecessary visits that burden the institution and society.

Although most patients are on return visits, already familiar with the service routine, or who were already aware of the procedures, there was no significant difference in opinion regarding service quality, when compared to first-time cases.

Patients in this study generally stated to be satisfied with the rendered service and positively appraised the quality of provided service. One would expect that in developing countries, users of public services demonstrate dissatisfaction with the provided service, because access to assistance of good quality is still a privilege for a few. Data gathered during investigations that approach the subject contradict this assumption $^{(10,16)}$.

The discrepancy found between the declared problems and the high degree of ophthalmology clinic users' satisfaction may be explained by the fact that the problems faced by them may not be relevant if compared to either the quality of attention received or the lack of another health service option to be utilized ${ }^{(16-17)}$. The degree of satisfaction observed may also be the result of a clientele with poor knowledge, with few financial resources and socially discriminated. In this case, any help coming during a moment of need is received with great satisfaction.

Maybe a better understanding of factors that determine dissatisfaction should be seeked. The fact that patients find it difficult to express their dissatisfaction must be carefully considered in future applications of studies of this kind. This would allow for an enhancement in the quality of the indicators, especially the anthropological-social ones, whose major vectors are the patients' accessibility and satisfaction. Perception of a state of satisfaction is subjective, but acknowledged as of value when one seeks to identify problems that compromise the quality of service ${ }^{(4)}$.

Qualitative studies reported that, in spite of a high degree of satisfaction expressed by the patients, further surveys indicated negative experiences and perceptions that are not reflected by questionnaires and that recommend to pay attention to rates of dissatisfaction ${ }^{(18)}$. To avoid this difficulty the questionnaire was based on an exploratory study. Accomplishment of this kind of study allows for the obtainment of data that reflect the perception of others and not only that of the surveyor ${ }^{(19)}$.

In general, surveys fail to address problems related to the fact that patients do encounter difficulties in formally expressing themselves in terms of dissatisfaction with health servi- ces. This suggests that research needs to develop new ways of eliciting user views which more faithfully match the respondents' meanings ${ }^{(20)}$.

In general, interviews conducted within the premises where health care is provided could lead the person who is answering the questions to please the interviewer. Due to this fact, interpretation of this result should be made with caution.

To expose oneself to evaluation means to run the risk of being considered less perfect than would be desired. At the same time, it means an increase in the probability of having better results.

The ophthalmology clinic at UNICAMP is a referral service within the public health system, with integrated assistance and teaching and a technological infrastructure that few services have, but its experience cannot be automatically transferred to other situations. Nevertheless, the evaluation performed allowed for a better knowledge about services provided by a teaching hospital and has shown the possibility of implementation of routines for the review of the quality of these services. The introduction of routines for evaluation of health service quality must guide modifications and introduction of new methods for improvement in assistance.

Although these results are related to a university hospital, these factors may probably be present in secondary and tertiary level services, reinforcing the necessity for this kind of survey regarding this issue and also the continuity of studies searching for better assistance to patients.

\section{RESUMO}

Objetivo: Avaliar características e satisfação de pacientes do ambulatório de oftalmologia de um hospital universitário, com vistas a obter subsídios para a padronização de um sistema de avaliação de qualidade. Método: Realizou-se estudo transversal analítico. Foi selecionada amostra de pacientes atendidos no ambulatório de Oftalmologia do Hospital das Clínicas da Universidade de Campinas (UNICAMP). Aplicou-se por entrevista, questionário estruturado incluindo as variáveis: características pessoais (sexo, idade, escolaridade, exercício de atividade remunerada), tempo de espera para obter a consulta, opinião em relação à facilidade de acesso ao serviço, atendimento da recepção, tempo despendido na sala de espera, qualidade do atendimento recebido e satisfação com o atendimento. Resultados: A amostra caracteriza-se por pacientes com escolaridade e nível socioeconômico baixos, e 21,7\% exercem atividade remunerada. A maioria considera fácil obter consulta nesse serviço oftalmológico. O tempo médio na sala de espera referido foi de 94,6 minutos e $45,3 \%$ dos pacientes afirmam não terem recebido orientações na pós-consulta. Os pacientes encontram-se satisfeitos com o atendimento recebido e fazem avaliação positiva da qualidade do serviço prestado. Conclusões: Embora seja observado alto grau de satisfação com os serviços, em geral, quando diferentes fatores que podem influenciar a satisfação são abordados os pacientes apontam limitações à qualidade. A avalia- 
ção permitiu melhor conhecimento sobre os serviços oferecidos em hospital-escola e evidenciou a possibilidade de implantação de rotinas de revisão da qualidade desses serviços.

Descritores: Satisfação do paciente; Satisfação dos consumidores; Qualidade dos cuidados de saúde; Qualidade da assistência à saúde, acesso e avaliação; Garantia de qualidade dos cuidados de saúde

\section{REFERENCES}

1. Nogueira RP. Perspectivas da qualidade em saúde. Rio de Janeiro: Qualitymark; 1994.

2. Malik AM, Teles JP. Hospitais e programas de qualidade no Estado de São Paulo. RAE. 2001;41(3):51-9.

3. Donabedian A. The quality of care. How can it be assessed? JAMA. 1988;260 (12):1743-8.

4. Sullivan M. The new subjective medicine: taking the patient's point of view on health care and health. Soc Sci Med. 2003;56(7):1595-604.

5. Uchimura KY, Bosi MLM. Qualidade e subjetividade na avaliação de programas e serviços em saúde. Cad Saúde Pública = Rep Public Health. 2002;8(6): 1561-9.

6. Temporini ER. A pesquisa na ciência oftalmológica - o que investigar? Sinopse Oftalmol. 2002;4(1):15-7.

7. Cohen G, Forbes J, Garraway M. Can different patient satisfaction survey methods yield consistent results? Comparison of three surveys. BMJ. 1996;313 (7061):841-4.

8. Felisberto E, Samico I. Qualidade na atenção à saúde: uma experiência de avaliação - à procura da satisfação do usuário. Rev IMIP. 1999;13(2):128-37.
9. Kloetzel K, Bertoni AM, Irazoqui MC, Campos VPG, Santos RN. Controle de qualidade em atenção primária à saúde. I - A satisfação do usuário. Cad Saúde Pública = Rep Public Health. 1998;14(3):623-8.

10. Junqueira LAP, Auge APF. Qualidade dos serviços de saúde e satisfação do usuário. Cad FUNDAP. 1995;19:60-78.

11. Gentil RM, Leal SMR, Scarpi MJ. Avaliação da resolutividade e da satisfação da clientela de um serviço de referência secundária em oftalmologia da Universidade Federal de Säo Paulo - UNIFESP. Arq Bras Oftalmol. 2003;66(2): 159-65.

12. Mendoza-Sassi R, Béria JU, Barros AJD. Outpatient health service utilization and associated factors: a population-based study. Rev Saúde Pública = J Public Health. 2003;37(3):372-8.

13. Leite Arieta CE, José NK, Carvalho Filho DM, Ruiz Alves M. Optimization of a university cataract-patient care service in Campinas, Brazil. Ophthalmic Epidemiol. 1999;6(2):113-23.

14. José NK, Arieta CEL, Temporini ER, Kang KM, Ambrosio LE. Tratamento cirúrgico de catarata senil: óbices para o paciente. Arq Bras Oftalmol. 1996; 59(6):573-7.

15. Santos SR, Andrade CPR, Magalhães ASO. Qualidade total na perspectiva da satisfação do paciente. Rev Bras Ciênc Saúde. 1997;1(1/3):57-62.

16. Franco SC, Campos GWS. Avaliação da qualidade de atendimento ambulatorial em pediatria em um hospital universitário. Cad Saúde Pública $=$ Rep Public Health. 1998;14(1):61-70.

17. Espinosa RM, Juarez SM, Del Campo DL, Carreño ET. The quality of outpatient services in health facilities in Hidalgo, Mexico, from the users' perspective. Rev Panam Salud Publica. 2003;13(4):229-38. Id: Spa.

18. Collins K, O'Cathain A. The continuum of patient satisfaction - from satisfied to very satisfied. Soc Sci Med. 2003;57(12):2465-70.

19. Piovesan A, Temporini ER. Pesquisa exploratória: procedimento metodológico para o estudo de fatores humanos no campo da saúde pública. Rev Saúde Pública = J Public Health. 1995;29(4):318-25.

20. Williams B, Coyle J, Healy D. The meaning of patient satisfaction: an explanation of high reported levels. Soc Sci Med. 1998;47(9):1351-9. 